\title{
INHIBITORY EFFECT OF CINNAMOMUM ZEYLANICUM BLUME (LAURACEAE) ESSENTIAL OIL AND $\beta$-PINENE ON THE GROWTH OF DEMATIACEOUS MOULDS
}

\author{
Ana Carolina Pessoa Moreira ${ }^{1}$; Edeltrudes de Oliveira Lima² ${ }^{2}$ Evandro Leite de Souza ${ }^{3 *}$; \\ Monique Araújo Van Dingenen²; Vinícius Nogueira Trajano²
}

${ }^{1}$ Laboratório de Tecnologia Farmacêutica, Departamento de Ciências Farmacêuticas, Centro de Ciências da Saúde, Universidade Federal da Paraíba, João Pessoa, PB, Brasil; ${ }^{2}$ Laboratório de Micologia, Departamento de Ciências Farmacêuticas, Centro de Ciências da Saúde, Universidade Federal da Paraíba, João Pessoa, PB, Brasil; ${ }^{3}$ Departamento de Nutrição, Centro de Ciências da Saúde, Universidade Federal da Paraíba, João Pessoa, PB, Brasil

Submitted: June 19, 2006; Returned to authors for corrections: July 27, 2006; Approved: January 18, 2007

\begin{abstract}
Dematiaceous moulds are pathogen microorganisms able to act as etiological agents of mycoses with different degrees of severity. This study evaluated the effectiveness of Cinnamomum zeylanicum Blume essential oil and $\beta$-pinene in inhibiting the growth of various strains of dematiaceous moulds (Alternaria brassicola, Cladosporium herbarium, C. resinae, C. cladosporioides, Chaetomum globosum, Curvularia sp., Fonsecaea compacta, Piedraia hortae). Antimicrobial assays were led by determining the Minimum Inhibitory Concentration-MIC using the solid medium diffusion procedure and observing the interference of the MIC values on the mould radial mycelial growth along 14 days. MIC values found to C. zeylanicum essential oil oscillated between 63 and $125 \mu \mathrm{L} / \mathrm{mL}$. $\beta$-pinene showed MIC value of $125 \mu \mathrm{L} / \mathrm{mL}$ for the most mould strains, however $C$. resinae and $C$. globosum were resistant to it in all assayed concentrations. MIC values found to C. zeylanicum essential oil and $\beta$-pinene presented intense fungicidal effect noted by atal inhibition of the mycelial growth of $C$. cladosporioides and $F$. compacta along 14 days of exposure. These results showed the intense antimould potential of $C$. zeylanicum essential oil and $\beta$-pinene which could be regarded in a rational use in pharmaceutical formulations used to treat some mycoses, particularly, those caused by dematiaceous moulds.
\end{abstract}

Key-words: dematiaceous moulds, Cinnamomum zeylanicum Blume, $\beta$-pinene, antimould activity

\section{INTRODUCTION}

Dematiaceous or demaceous moulds are characterized by presenting malaninogenic pigmentation in their cell walls, which is the main characteristic of the dark moulds group. Some authors have known the dematiaceous moulds as opportunistic pathogens generally with low pathogenicity which could get into the human or animal body by repeated traumatic inoculation (31,32). Piedrae hortae, Hortae werneckii, Hendersonula toruloidea, Chaetomium globosum, Curvularia sp., Cladosporium sp., Alternaria sp., Fonsecaea sp., Exophiala and Phialophora sp. are some dematiaceous moulds known as potential etiological agents of various mycoses with clinical forms ranging from localized superficial infections of the stratum corneum (tinea nigra) to subcutaneous cysts (phaeomycotic cyst) to invasion of the brain $(28,29)$. The anti-dematiaceous moulds therapy has been carried out by the use of some antibiotics as amphotericin B, 5-fluorocitosin and itraconazole $(20,25)$.

The medicinal use of plants is spread all over the world in the folk medicine (14). Based on this wide use of plants for medicinal purposes, over than 1.500 plants have been scientifically studied regarding their phytochemical profile and pharmacological properties $(9,19)$. Antifungical activity of

*Corresponding Author. Mailing address: Rua Radialista Antônio Assunção de Jesus, 680/102, 58052-230, João Pessoa, PB, Brasil. E-mail: evandroleitesouza@bol.com.br 
medicinal plants and derivatives has been scientifically proved in assays with essential oils, extracts, phytoalexins, cumarins, terpenes, flavonoids, amides, imides and alkaloids $(3,7,10,26)$.

Cinnamomum zeylanicum Blume, Lauraceae family, which presents Laurus cinnamomum Linn. or Cinnamomum cassia Linn. as scientific synonym, has showed many biological properties as analgesic, antiseptic, antispasmodic, aphrodisiac, astringent, carminative, insecticidal and parasiticide. $C$. zeylanicum is native of Indonesia being widely cultured in many Brazilian regions $(2,30)$. Its branch peel without the epidermis and subereous layer is marketed as the commercial cinnamon which has been used a long in perfumery, culinary and native medicine systems $(11,18)$. $\beta$-pinene is a phytochemical chemically characterized as a hydrocarbon being inserted in the terpenic compounds class and found in essential oils of several plants with therapeutic properties. $\beta$-pinene is known as one of the majority compounds of $C$. zeylanicum essential oil $(5,21)$.

Antimicrobial activity of plant products (extracts, essential oils and phytochemicals) has been showed for some researches $(9,15,24)$, but there is a lack of studies regarding the antimicrobial effectiveness of plant products and derivatives on dematiaceous moulds. This study was led with the purpose of evaluating the inhibitory effect of C. zeylanicum essential oil and $\beta$-pinene on the growth of some dematiaceous mould strains.

\section{MATERIALAND METHODS}

\section{Essential oil}

Cinnamomum zeylanicum Blume essential oil was supplied by Ferquima Ind. Com. Ltda. (Vargem Grande Paulista, São Paulo, Brazil) and its quality parameters: appearance, color, purity, odor, density $-20^{\circ} \mathrm{C}$, refraction index $-20^{\circ} \mathrm{C}$ were described in a accompanying technical report. This provider produces and commercializes essential oils on an industrial scale. $\beta$-pinene was supplied by Laboratory of Pharmacotechnique, Department of Pharmaceutical Sciences, State University of Ponta Grossa, Paraná, Brazil.

\section{Moulds strains}

Alternaria brassicola (ATCC-6650), Cladosporium herbarium (ATCC-26362), C. resinae (ATCC-22712), C. cladosporioides (ATCC-16022), Chaetomium globosum (ATCC-6205), Curvularia sp. (LM-4), Fonsecaea compacta (LM-56) and Piedraia hortae (LM-2) strains were used as test microorganisms. The strains were taken from the Microorganisms Collection, Laboratory of Mycology, Department of Pharmaceutical Sciences, Health Sciences Center, Federal University of Paraíba, João Pessoa, Brazil. Stock cultures were maintained on Sabouraud agar (SA) slants and stored in a refrigerator.

\section{Minimum Inhibitory Concentration - MIC}

MIC determination was carried out by a qualitative method using the solid medium diffusion procedure (12). For this, $1 \mathrm{~mL}$ of mould homogenous suspension (approximately $10^{6}$ spores) prepared according to Rana et al. (23) was uniformly spread on sterile SA Petri dishes. After inoculum absorption by SA, wells were made using sterile glass stems (diameter $6 \mathrm{~mm}$ ) which were filled with $50 \mu \mathrm{L}$ of the essential oil or phytochemical solution. The different concentration solutions used in the MIC assay were $500,250,125,63,32,18$ and $9 \mu \mathrm{L} / \mathrm{mL}$ which were prepared according to Gayoso et al. (11). The incubation period was 7-10 days at $25^{\circ} \mathrm{C}$. At the end of the incubation period, the MIC was the lowest concentration showing growth inhibition halos with diameters equal to or greater than $10 \mathrm{~mm}(16,27)$.

Control was carried out with amphotericin B $(100 \mu \mathrm{g} / \mathrm{mL})$ by solid medium diffusion procedure using filter paper discs (Cecon, diameter $6 \mathrm{~mm}$ ) (4). Also, it was carried out the control of viability of the assayed mould strains by observing their capability of growing on SA without adding essential oil or phytochemical. Each antimicrobial assay was performed twice and the results were expressed as the average of the two repetitions.

\section{Mycelial growth inhibition}

Inhibition of the dematiaceous moulds mycelial growth was determined using the poisoned substrate technique by the daily measure of the radial mycelial growth on SA added of the essential oil or phytochemical in a amount adjusted to provide a final concentration similar to the MIC previously determined $(1,7)$. For this, a $2 \mathrm{~mm}$ plug taken from a 10 days old mould culture cultivated on SA slants were placed on the center of the sterile SA Petri dishes added of the essential oil or phytochemical prior to the assay and incubated at $25-27^{\circ} \mathrm{C}$ for 10 days. At different intervals (1, 2, 4, 6, 9 and 14 days) after incubation, the mould radial mycelial growth was measured $(\mathrm{mm})$ using calipers. Control included in this assay was the observation of the mould radial growth on SA without adding essential oil or phytochemical, and added of amphotericin B $(100 \mu \mathrm{g} / \mathrm{mL})$.

\section{Statistical analysis}

Statistical analysis was performed to determine significant differences $(P<0.05)$ by Tukey test in the assays of mould mycelial growth inhibition. For this was used Sigma stat 2.03 computer program.

\section{RESULTS AND DISCUSSION}

Inhibition growth of the dematiaceous moulds strains by $C$. zeylanicum essential oil and $\beta$-pinene was assessed using a qualitative approach by the solid medium diffusion technique, as well as using a quantitative approach by the measure of the mould mycelial radial growth in different times of exposure. MIC values found to $C$. zeylanicum essential oil and $\beta$-pinene against 
the assayed dematiaceous moulds strains are shown in Table 1. In general, $C$. zeylanicum essential oil and $\beta$-pinene presented effectiveness in inhibiting the growth of the dematiaceous moulds strains. All assayed strains were sensitive to $C$. zeylanicum essential oil showing MIC values oscillating between 63 to $125 \mu \mathrm{L} / \mathrm{mL}$. $\beta$-pinene presented MIC values between 63 to $125 \mu \mathrm{L} / \mathrm{mL}$ for the most moulds strains. $C$. resinae and $C$. globosum were resistant to $\beta$-pinene in all assayed concentrations, however they presented the smallest MIC values found for $C$. zeylanicum essential oil. As can be seen, all mould strains that showed resistance for the standard antifungical (amphotericin B) were sensitive to the tested natural products.

The effect of $C$. zeylanicum essential oil $(125 \mu \mathrm{L} / \mathrm{mL})$ and $\beta$ pinene $(62.5$ and $125 \mu \mathrm{L} / \mathrm{mL})$ on the kinetic of the radial mycelial growth of $C$. cladosporioides and $F$. compacta are shown in Figure 1,2, 3 and 4 . The natural products presented a statistically significant $(P<0.05)$ inhibitory effect on the mould growth causing a total inhibition of the mycelial growth along the different evaluated intervals. C. cladosporioides showed a trend to establish a small growth after 2 days until 9 days of exposure however presenting a radial growth diameter always smaller than $5 \mathrm{~mm}$. On the other hand, from 9 days on no growth increase was noted. Amphotericin B did not show capability to develop a significant inhibitory effect on the mould mycelia growth along 14 days of exposure. In general, the mould strains when exposed to amphotericin B $(100 \mu \mathrm{g} / \mathrm{mL})$ developed a progressive increasing in their mycelial growth showing a growth profiles similar to the ones found in the control assays.

Regarding the MIC values (no resistance) and the inhibition of the mould mycelial growth (total inhibition in all evaluated intervals), the $C$. zeylanicum essential oil showed a more intense antimould effect when compared to $\beta$-pinene, so that it could indicate a synergic effect among the phytochemicals present in the assayed essential oil. This synergic effect means that $\beta$-pinene

Table 1. MIC of $C$. zeylanicum essential oil and $\beta$-pinene on the growth of dematiaceous moulds.

\begin{tabular}{cccc}
\hline \multirow{2}{*}{ Mould strains } & \multicolumn{2}{c}{$\mathrm{MIC}(\mu \mathrm{L} / \mathrm{mL})$} & $\begin{array}{c}\text { amphotericin B } \\
(100 \mu \mathrm{g} / \mathrm{mL})\end{array}$ \\
\cline { 2 - 3 } & $\begin{array}{c}\text { C. zeylanicum } \\
\text { essential oil }\end{array}$ & $\beta$-pinene & \\
\hline A. brassicola & 125 & 125 & $\mathrm{~S}$ \\
C. herbarium & 125 & 125 & $\mathrm{~S}$ \\
C. resinae & 63 & $\mathrm{R} *$ & $\mathrm{~S}$ \\
C. cladosporioides & 125 & 125 & $\mathrm{R}$ \\
C. globosum & 63 & $\mathrm{R} *$ & $\mathrm{~S}$ \\
Curvularia sp. & 125 & 125 & $\mathrm{~S}$ \\
F. compacta & 125 & 63 & $\mathrm{R}$ \\
P. hortae & 125 & 125 & $\mathrm{R}$ \\
\hline
\end{tabular}

$\mathrm{S}$ : sensitive; R: resistant; $\mathrm{R}^{*}$ : resistant for all assayed concentrations.

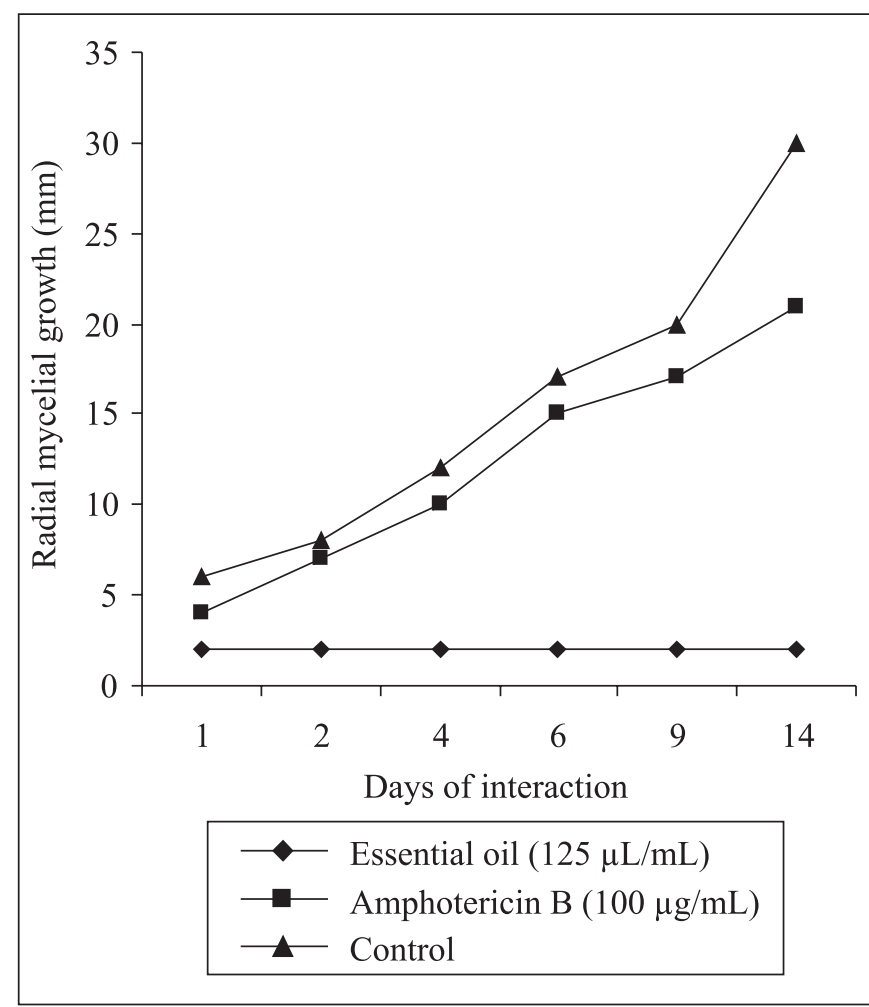

Figure 1. Effect of C. zeylanicum essential oil and amphotericin $\mathrm{B}$ on the radial mycelial growth kinetic of $C$. cladosporioides.

could present higher antimould activity when acting concomitantly to other phytochemicals (e.g. canfen, linalool, $\alpha$-phelandren, $\alpha$ terpinene, limonene, $\mathrm{p}$-cymene, $\beta$-cariophyllene, aldheyde cynamic, eugenole) found in C. zeylanicum essential oil.

Antimicrobial activity of $C$. zeylanicum has been studied on Gram positive and Gram negative bacteria, viruses, moulds and yeasts and the results have ranged according to the microorganism and assayed product (essential oil, extracts, decoct, plant powder). Researches regarding the antimicrobial activity of phytochemicals have been yet little emphasized being the most studies addressed to the antimicrobial effect of essential oils and extracts. In truth, there is a lack of scientific data showing the antimicrobial property of pinenes, although the antimicrobial activity of some phytochemicals has been reported $(8,13,22)$. Gayoso et al. (10) found intense fungicidal effect of pinenes (20 and $40 \mu \mathrm{L} / \mathrm{mL}$ ) on onychomycosis causing fungi (Candida albicans, C. tropicalis, C. krusei, Trichophyton rubrum, $T$. mentagrophytes and Geotrichum candidum) causing a total elimination of the fungal cell viability after 5 hours of exposure. Lima et al. (17) found intense antiyeast activity of $\beta$-pinene $(40 \mu \mathrm{L} / \mathrm{mL})$ on various Candida species noting a fungicide effect on $C$. albicans, C. krusei and $C$. neoformans between 1 and 3 hours of exposure. 


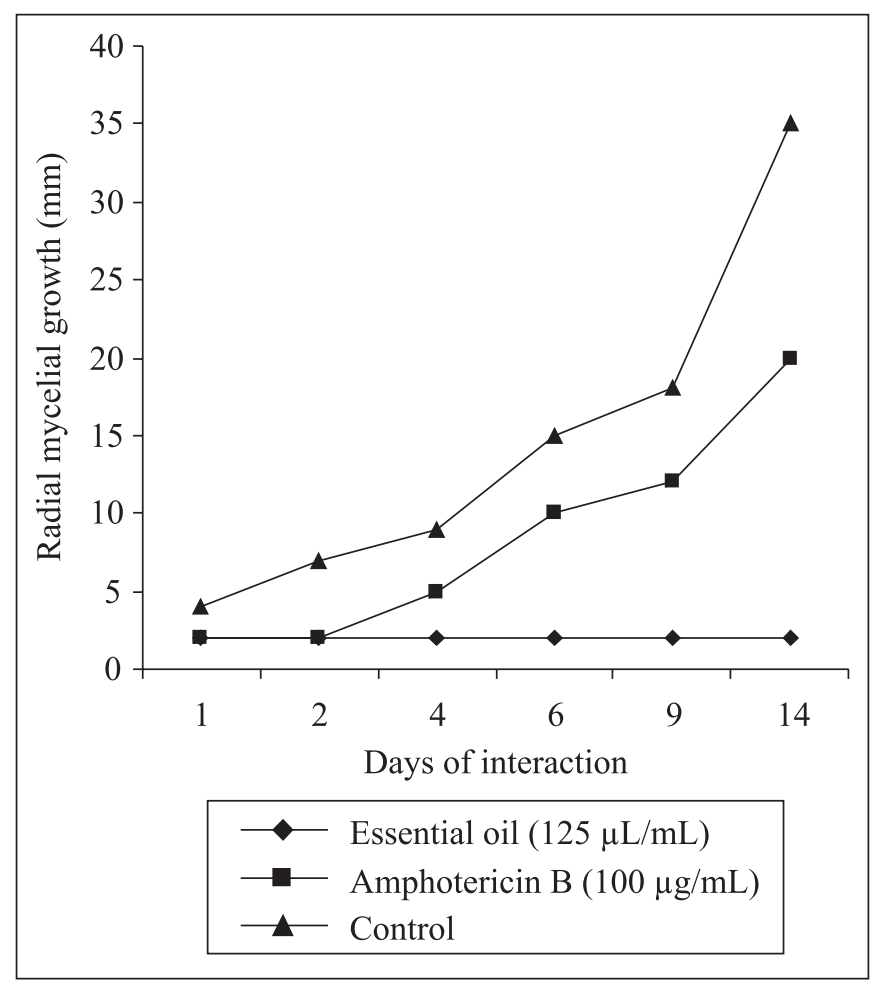

Figure 2. Effect of $C$. zeylanicum essential oil and amphotericin B on the radial mycelial growth kinetic of $F$. compacta.

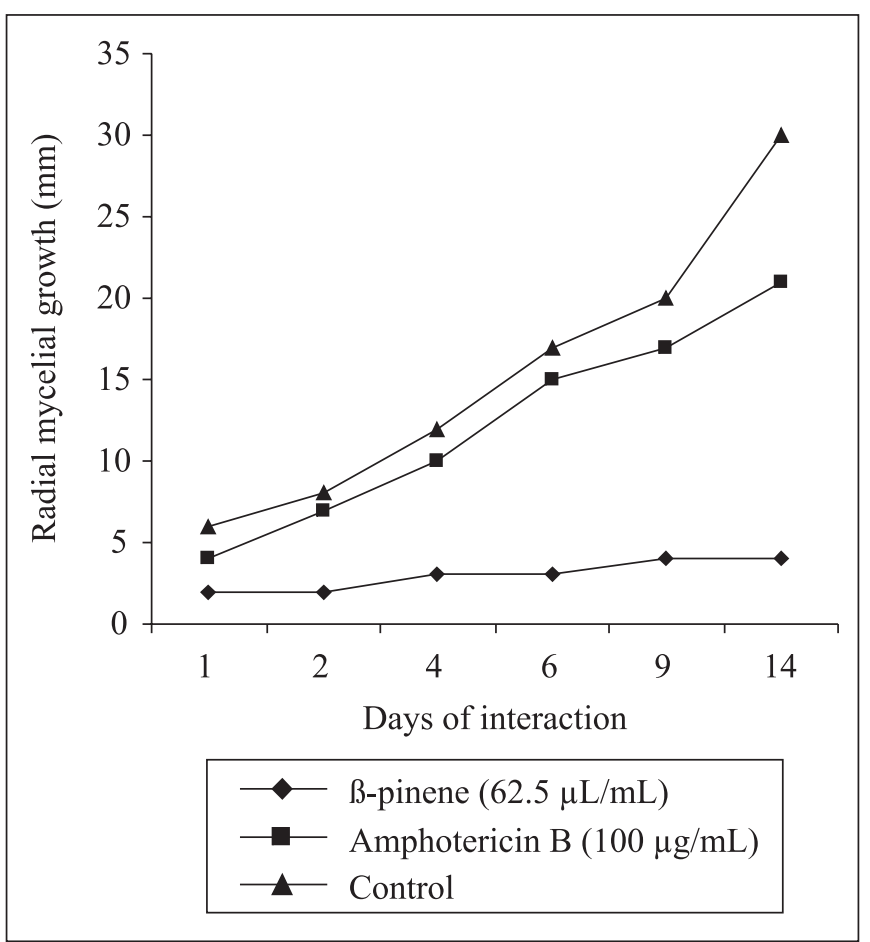

Figure 3. Effect of $\beta$-pinene and amphotericin $B$ on the radial mycelial growth kinetic of $C$. cadosporioides.

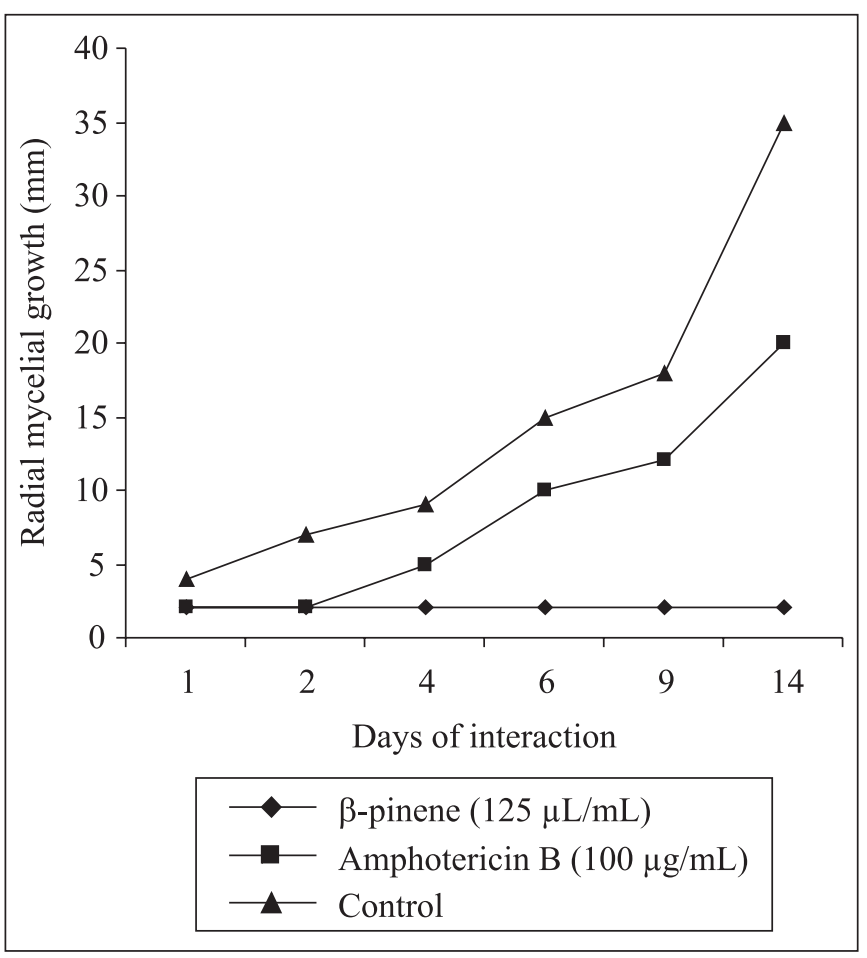

Figure 4. Effect of $\beta$-pinene and amphotericin $B$ on the radial mycelial growth kinetic of $F$. compacta.

Phytochemicals are small organic biomolecules generally hydrophobic and designated as naturally occurring antibiotics $(5,6,8)$. Antifungal property of phytochemicals could involve citossolic hyperacidity, breakage of electrons transport chain, cytoplasm membrane disturbing, $\mathrm{H}^{+}$-ATPase inhibition, channels inhibition and intracellular and extracellular enzymes synthesis inhibition $(18,27)$.

Data from our study has confirmed the antimicrobial potential of plant products, particularly the antimould effect of $C$. zeylanicum essential oil and $\beta$-pinene noted by small MIC values and total inhibition of the mycelial growth of the assayed dematiaceous moulds strains. Moreover, our findings show that C. zeylanicum essential oil and $\beta$-pinene could arise as promising alternative antimicrobial compounds to be inserted in pharmaceutical formulations used to treat mycoses of different clinical severities caused by dematiaceous moulds.

\section{RESUMO}

\section{Efeito inibitório do óleo essencial de Cinnamomum zeylanicum Blume (Lauraceae) e $\beta$-pineno sobre o crescimento de fungos dematiáceos}

Os fungos dematiáceos são microrganismos patogênicos capazes de agir como agentes etiológicos de micoses com 
diferentes graus de severidade. Este estudo avaliou a efetividade do óleo essencial de Cinnamomum zeylanicum Blume e $\beta$-pineno em inibir o crescimento de várias cepas de fungos dematiáceos (Alternaria brassicola, Cladosporium herbarium, C. resinae, C. cladosporioides, Chaetomum globosum, Curvularia, Fonsecaea compacta, Piedraia hortae). Os ensaios antimicrobianos foram conduzidos através da determinação da Concentração Inibitória Mínima-CIM utilizando-se da técnica de difusão em meio sólido, bem como através da observação da interferência dos valores de CIM sobre o crescimento micelial radial fúngico ao longo de 14 dias. Os valores de CIM encontrados para o óleo essencial de C. zeylanicum oscilaram entre 63 e $125 \mu \mathrm{L} / \mathrm{mL}$. $\beta$-pineno apresentou um valor de CIM de $125 \mu \mathrm{L} / \mathrm{mL}$ para a maioria das cepas fúngicas, entretanto $C$. resinae e C. globosum mostraram-se resistentes a todas as concentrações ensaiadas. Os valores de CIM encontrados para C. zeylanicum e $\beta$-pineno apresentaram intenso efeito fungicida notado por uma total inibição do crescimento micelial de $C$. cladosporioides e F. compacta ao longo de 14 dias de exposição. Estes resultados mostraram o intenso potencial antifúngico do óleo essencial de $C$. zeylanicum e $\beta$-pineno, os quais poderiam ser considerados em um uso racional em formulações farmacêuticas utilizadas para a terapia de algumas micoses, particularmente, aquelas causadas por fungos dematiáceos.

Palavaras-chave: fungos dematiáceos, Cinnamomum zeylanicum Blume, $\beta$-pineno, atividade antifúngica

\section{REFERENCES}

1. Adam, K.; Sivropoulou, A.; Kokkini, S.; Lanaras, T.; Arsenakis, M. (1998). Antifungal activities of Origanum vulgare subsp. hirtum, Mentha spicata, Lavandula angustifolia, and Salvia fruticosa essential oils against human pathogenic fungi. J. Agric. Food Chem., 46(5), 1739-1745.

2. Almeida, E.R. (1993). Plantas medicinais brasileiras. Hemus Editora, São Paulo.

3. Aquino, P.L.P.; Lima, E.O.; Farias, M.P.; Freire, K.R.L.; Souza, E.L.; Cechinel Filho, V.; Corrêa, R.; Andricopulo, A. (2003). Atividade antifúngica de maleimidas contra dermatófitos isolados de Tinea captis. Rev. Bras. Anal. Clin., 35(4), 191-194.

4. Bauer, A.W.; Kirby, W.M.M. (1966). Antibiotic susceptibility testing by standardized single disk method. Am. J. Clin. Pathol., 45(2), 493496.

5. Brul, S.; Coote, P. (1999). Preservative agents in foods: mode of action and microbial resistance mechanisms. Int. J. Food Microbiol., 50(1-2), 1-17.

6. Burt, S. (2004). Essential oils: their antibacterial properties and potential applications in foods - a review. Int. J. Food Microbiol., 94(3), 223-253

7. Daferera, D.J.; Ziogas, B.N.; Polissiou, M.G. (2003). The effectiveness of plant essential oils on the growth of Botrytis cinerea, Fusarium sp. and Clavibacter michiganenesis subsp. michiganenesis. Crop. Protect., 22(1), 39-34.

8. Delaquis, P.J.; Mazza, G. (1995).Antimicrobial properties of isothiocyanate in food preservation. Food Technol., 49(1), 7384 .
9. Duarte, M.C.T.; Figueira, G.M.; Sartoratto, A.; Rehder, V.L.G.; Delarmelina, C. (2005). Anti-Candida activity of Brazilian medicinal plants. J. Ethnopharm., 97(2), 305-311.

10. Gayoso, C.W.; Lima, E.O.; Oliveira, V.T.; Pereira, F.O.; Souza, E.L.; Lima, I.O.; Navarro, D.F. (2005). Sensitivity of fungi isolated from onychomycosis to Eugenia cariophyllata essential oil and eugenol. Fitoterapia, 76(2), 247-249.

11. Gayoso, C.W.; Lima, E.O.; Souza, E.L. (2004). Ação inibitória do óleo essencial de Cinnamomum zeylanicum Blume, $\alpha$-pineno e $\beta$ pineno sobre fungos isolados de onicomicoses. J. Bras. Fitomed., 1 (1-4), 25-29.

12. Hadacek, F.; Greger, H. (2000). Testing of antifungal natural products: methodologies, comparability of results and assay choice. Phytochem. Anal., 11(3), 137-148.

13. Helander, L.M.; Alakomi, H.L.; Latva-Kala, K.; Mattila-Sandholm, T.; Pol, I.; Smid, E.J.; Gorris, L.G.M.; von Wight, A. (1998). Characterization of the action of selected essential oil components on gram-positive bacteria. J. Agric. Food Chem., 46(9), 3590-3595.

14. Hernández, T.; Canales, M.; Avila, J.G.; Duran, A.; Caballero, J.; Romo de Vivar, A.; Lira, R. (2003). Ethnobotany and antibacterial activity of some plants used in traditional medicine of Zapotitán de las Salinas, Puebla (México). J. Ethnopharm., 88(1), 181-188.

15. Lima, E. O.; Queiroz, E. F.; Andricopulo, A.D.; Yunes, R.A.; Corrêa, R.; Cechinel Filho, V. (1999). Evaluation of antifungal activity of $\mathrm{N}$-aryl-maleimides and $\mathrm{N}$-phenylalkyl-3,4-dichloro-maleimides. Bol. Soc. Chil. Quim., 44(2), 185-189.

16. Lima, E.O.; Gompertz, O.F.; Giesbrecht, A.M.; Paulo, M.Q. (1993). In vitro antifungal activity of essential oil obtained from officinal plants against dermatophytes. Mycoses, 36(9-10), 333-336.

17. Lima, I.O.; Oliveira, R.A.G.; Lima, E.O.; Souza, E.L.; Farias, N.P.; Navarro, D.F. (2005). Inhibitory action of some phytochemicals on yeasts potentially causing of opportunistic infections. Rev. Bras. Cien. Farm., 41(2), 199-203.

18. Lopez Diaz, T.M.L.; González, C.J.; Moreno, B.; Otero, A. (2002). Effect of temperature, water activity, $\mathrm{pH}$ and some antimicrobials on the growth of Penicillium oslonii isolated from the surface of Spanish fermented meat sausage. Food Microbiol., 19(1), 1-7.

19. Mansaray, M.O. Herbal remedies - food or medicine? (2000) Chem. Ind., 20(16), 677-678.

20. Minotto, R.; Bernardi, C.D.V.; Mallman, L.F.; Edelweiss, M.I.A.; Scroferneker, M.L. (2001). Chromoblastomycosis: a review of 100 cases in the state of Rio Grande do Sul, Brazil. J. Am. Acad. Dermatol., 44(4), 585-592.

21. Misra, N.; Upma, K.; Shukla, D. (2000). Antifungal activity of essential oil of Cinnamomum zeylanicum. J. Essential Oil Res., $3(1), 97-110$.

22. Nascimento, G.G.F.; Locatelli, J.; Freitas, P.C.; Silva, G.L. (2000). Antibacterial activity of extracts and phytochemicals on antibioticresistant bacteria. Braz. J. Microbiol., 31(4), 245-256.

23. Rana, B.K.; Singh, U.P.; Taneja, V. (1997). Antifungal activity and kinetics of inhibition by essential oil isolated from leaves of Aegle marmelos. J. Ethnopharm., 57(1), 29-34.

24. Sahin, F.; Gulluce, M.; Daferera, D.; Sokmen, A.; Sokmen, M.; Polissiou, M.; Agar, G.; Ozer, H. (2004). Biological activities of the essential oils and methanol extract of Origanum vulgare ssp. vulgare in the Eastern Anatolia region of Turkey. Food Control, 15(7), 549-557

25. Schwartz, R. Superficial fungal infections. (2004). Lancet 364 (9440), 1173-1182

26. Souza, E.L.; Lima, E.O.; Freire, K.R.L.; Sousa, C.P. (2005). Inhibitory action of some essential oils and phytochemicals on the growth of moulds isolated from foods. Braz. Arch. Biol. Technol., 48(2), 245-250.

27. Stangarlin, J.R.; Schwan-Estrada, K.R.; Cruz, M.E.S.; Nagaki, M.H. (1999). Plantas medicinais e controle de fitopatógenos. Biotecnol. Cien. Desenv., 2(1), 16-22. 
28. Tamsikar, J.; Naidu, J.; Singh, S.M. (2006). Phaeohyphomycotic sebaceous cyst due to Cladosporium cladosporioides: case report and review of literature. J. Med. Mycol., 16(1), 55-57.

29. Thibaudon, M.; Lachasse, C. (2006). Alternaria, Cladosporium: dispersion atmosphérique, rythmes nycthéméral et saisonnier. Revue Française d'Allergologie et d'Immunologie Clinique, 46(13), 188196.

30. Vieira, L.S. (1992). Fitoterapia da Amazônia. Editora Agrônomo Ceres, São Paulo.
31. Warnock, D.W.; Johnson, E.M. (1991). Clinical manifestations and management of hyalohypomycosis, phaeohypomycosis and other uncommon forms of fungal infection in the compromised patient. In: Warnock, D.W.; Richardson, M.D. (eds) Fungal infection in the compromised patient. Chichester, Ed. John Willey \& Sons, Chichester, p.756-789.

32. Wilhelmus, K.R. (2005). Climatology of dematiaceous fungal keratitis. Am. J. Ophthalmol., 140(6), 1156-1157. 